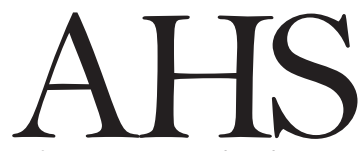

Advances in Horticultural Science

\title{
Effect of biostimulants and media com- positions on growth and yield of Capsicum annuum L. under drought stress conditions
}

\author{
B. Ichwan, E. Eliyanti, Z. Zulkarnain (*) \\ Department of Agroecotechnology, Faculty of Agriculture, University of \\ Jambi, Jambi, Indonesia.
}

Key words: chili pepper, drought stress, growth stimulant, organic farming, sustainable agriculture, Trichoderma.

OPEN ACCESS

${ }^{(*)}$ Corresponding author:

dr.zulkarnain@yahoo.com

\section{Citation:}

ICHWAN B., ELIYANTI E., ZULKARNAIN Z., 2021 Effect of biostimulants and media compositions on growth and yield of Capsicum annuum $L$. under under drought stress conditions. - Adv. Hort. Sci., 35(2): 129-137

\section{Copyright:}

(c) 2021 Ichwan B., Eliyanti E., Zulkarnain Z. This is an open access, peer reviewed article published by Firenze University Press

(http://www.fupress.net/index.php/ahs/) and distributed under the terms of the Creative Commons Attribution License, which permits unrestricted use, distribution, and reproduction in any medium, provided the original author and source are credited.

Data Availability Statement: All relevant data are within the paper and its Supporting Information files.

Competing Interests:

The authors declare no competing interests.

Received for publication 12 March 2020 Accepted for publication 19 March 2021
Abstract: The study was conducted at the Teaching and Research Farm of Agricultural Faculty, University of Jambi, Indonesia, from April through to September 2019. The aim of this study was to investigate the effect of biostimulants and media compositions on the growth and yield of chili pepper during restricted soil water content. The study was arranged in a split plot design with 3 replicates (groups). Different types of biostimulants (Citorin ${ }^{\circledR}, \mathrm{Hantu}^{\circledR}$, and a control) were designated as main plot, whereas media compositions (2:2:1, 2:1:1, 1:2:1 and 1:1:2) made of soil+trichocompost+rice husk charcoal were employed as sub plot. At the time of transplanting, soil water content was set to approximately $75 \%$ of field capacity to create stress conditions. The results showed that the proper choice of biostimulant and medium composition could increase nutrient status, total sugar and chlorophyll contents, and reduce proline level in plants grown under restricted water availability. Citorin ${ }^{\circledR}$ application on chili plants grown on organic media (soil+trichocompost+rice husk charcoal) with ratio of 2:1:1 could be recommended to support plant growth and production under drought stress conditions.

\section{Introduction}

Chili pepper (Capsicum annuum L.) is one of important vegetable crops in Indonesia which is cultivated almost throughout the country. The demand of this commodity has significantly increased, but the production is not yet able to meet the requirement. Current average yield of chili pepper is about 8.47 ton $\mathrm{ha}^{-1}$, and this was far lower than its potential yield that may reach 15-20 ton ha-1 (Statistics Indonesia, 2019). Therefore, efforts should be done to promote chili pepper production through the improvement of cultivation techniques and expansion of planting area.

The improvement of chili production through expansion of planting area both in dry and rainy season is restricted by uncertain condition of growing environment, resulting in poor plant growth and development. 
Chili pepper growing during dry season is constrained by limited soil water availability, causing environmental stress to the plants. Study by Ichwan et al. (2017) revealed that chili pepper grown under 50\% field capacity showed slow growth, reduced yield, high proline content, and low sugar content.

Efforts to improve the ability of chili plants to survive drought stress and to be able to grow and result in maximum yield can be done by applying effective biostimulants to plants grown under a mixture of soil, trichocompost and rice husk charcoal. The effect of biostimulant in enhancing plant growth and production had been reported by many authors (LópezBucio et al., 2015; Rady and Ur Rehman, 2016; Niyokuri et al., 2018; Drobek et al., 2019). Also, the use of trichocompost or Trichoderma-enriched compost in supporting plant growth and development under limited soil water content had been studied with positive results (Bae et al., 2009; Mastouri et al., 2010; Khoshmanzar et al., 2019).

The use of organic materials may increase plant tolerance to drought stress due to their ability to improve soil structure, increase aeration in root zone, reduce mass density, increase cation exchange capacity, and maintain primary nutrients such as $\mathrm{N}$ and $\mathrm{P}$, in addition to increasing soil water holding capacity. Trichocompost (Trichoderma in compost) is one of organic materials that can be used to improve plant resistance to drought stress. In addition, the application of husk charcoal in growing media is another way to enhance soil organic matter and improve chemical, physical and biological properties of soil. Husk charcoal contains $0.32 \% \mathrm{~N}, 15 \%$ PO, 31\% KO, 0.95\% Ca, 180 ppm Fe, 80 ppm Mn, 14.1 ppm Zn and $\mathrm{pH}$ 6.8. Another characteristic of husk charcoal is light (specific gravity of $0.2 \mathrm{~kg} \mathrm{~L}^{-1}$ ). Rice husk charcoal also increased field capacity and water content by increasing the porosity of the amended soil, and reduced the acidity of soil (Mishra et al., 2017).

Rice husk charcoal treatments on pot grown lettuce (Lactuca sativa) and cabbage (Brassica chinensis) were found to increase the final biomass, root biomass, plant height and number of leaves in all the cropping cycles in comparison to charcoal free treatments (Carter et al., 2013). Mannan and Shashi (2019) reported that the application of rice husk charcoal increased plant height, days to maturity, total dry weight, cob diameter, cob length, 100-grain weight, and yield of maize under drought conditions. Chlorophyll content was also found to increase, but proline content decreased due to rice husk charcoal application. Meanwhile, Imanda and Ketty (2018) claimed that rice husk charcoal along with cow manure was best composition for the growth of papaya plant. In chili pepper, however, study on the use of mixture of soil, trichocompost and rice husk charcoal, particularly under drought stress, is not yet well documented.

The application of biostimulant along with the improvement of growing media is expected to be synergistically improve the resistance of chili pepper against drought stress while sustaining best growth and yield. The purpose of this study was to obtain a proper combination of biostimulant and growing media compositions that enhance the growth and yield of chili pepper during drought stress.

\section{Materials and Methods}

\section{Experimental design and plant handling}

The study was conducted at the Teaching and Research Farm, Faculty of Agriculture, University of Jambi from April 2019 through to September 2019. A split plot design with three replications was employed in this study. The main plot consisted of different types of commercial mixed biostimulants (Citorin ${ }^{\circledR}$ and $\mathrm{Hantu}^{\circledR}$ ) and a control, while the subplot consisted of different ratio of soil+trichocompost+rice husk charcoal $(2: 2: 1,2: 1: 1,1: 2: 1$, and $1: 1: 2)$. The biostimulant Citorin ${ }^{\circ}$ contained gibberellic acid, $\mathrm{P}_{2} \mathrm{O}_{5}, \mathrm{~K} 2 \mathrm{O}, \mathrm{MgO}, \mathrm{Mn}$, antioxidant and vitamins (Amanah and Putra, 2018), and $\mathrm{Hantu}^{\circledR}$ contained gibberellic acid, indoleacetic acid, kinetin, zeatin, $\mathrm{N}$, $\mathrm{P}, \mathrm{Na}, \mathrm{Mg}, \mathrm{Cu}, \mathrm{Fe}, \mathrm{Mn}, \mathrm{Zn}, \mathrm{Co}, \mathrm{Cd}$, and $\mathrm{Pb}$ (Lidar and Mutryarny, 2017).

Seeds of chili pepper cv. Lado were sown on media consisted of soil+trichocompost+rice husk charcoal (2:1:1) on a seedbed. Seven days later seedlings were transferred to nursery, and left for 21 days before transplanting on individual pots with different media compositions according to the treatment. Soil water content in the media was set to $75 \%$ of field capacity to create drought condition, except those controls. This is in accordance with our previous investigation (Ichwan et al., 2017).

Biostimulants were applied to the plants on weekly basis from week $2^{\text {nd }}$ to week $12^{\text {th }}$ after transplanting by foliar spraying. Fertilization and maintenance of plants were carried out in accordance with the standard of chili pepper cultivation (Zulkarnain, 2013). 


\section{Variables observed}

Data on plant growth and yield were collected 10 weeks after transplanting (the time of fruit formation) and 14 weeks after transplanting (the time of first harvest). Variables observed were plant height, number of productive branches, total leaf area, dry weight (total and above-ground parts), fruit number, and total weight of fruits per plant.

\section{Chemical analysis}

Data on $\mathrm{N}, \mathrm{P}, \mathrm{K}^{+}, \mathrm{Ca}^{2+}$ and $\mathrm{Mg}^{2+}$ content in plant tissues were also recorded as well as total sugar, chlorophyll content, and proline content within leaf tissues. Composite leaf samples were made by physically mixing individual leaves taken from 3 sample plants of 3 replicates into one homogenous sample. Compositing reduced the number of analyses to be performed and was designed to provide a representative sample of the treatment. Ten youngest mature leaves on main stem were collected at 10 weeks after transplanting (WAT). Dry and clean leaf samples were placed in a sample bag prior to laboratory analysis.

Total nitrogen content was determined by Kjeldahl method (Labconco Corporation, 1998), phosphorus concentration was determined by vanadium molybdate yellow colorimetric method (Karlberg and Pacey, 1989), whereas $\mathrm{K}^{+}, \mathrm{Ca}^{2+}$ and $\mathrm{Mg}^{2+}$ were analysed using Atomic Absorption Spectrometry (AAS) method (The Perkin-Elmer Corporation, 1996). Total sugar was determined according to Irigoyen et al. (1992), chlorophyll content was determined according to Hall and Rao (1986), and proline content was analysed according to Bates et al. (1973).

\section{Statistical analysis}

Data were analysed statistically using Analysis of Variance (ANOVA) module (Petersen, 1985) to judge the significance of the effect of biostimulants and growing media compositions. If the result from ANOVA is significant $(p<0.05)$, then the Fisher's Least Significant Different (FLSD) is applied to see the difference between two treatment means. Any difference larger than FLSD is considered a significant result.

\section{Results}

There was no significant effect of biostimulants on plant height at 10 weeks after transplanting (WAT). However, significant response was shown by plants grown on different media compositions. In the absence of biostimulant, the composition of $2: 1: 1$, 1:2:1 and 1:1:2 were found to enhance plant height. When Citorin ${ }^{\circledR}$ was used as plant biostimulant, the medium composition of 1:1:2 was the best. However, with the use of biostimulant $\mathrm{Hantu}^{\circledR}$ none of medium composition showed significant effect on plant height (Table 1).

Table 1 - The effect of biostimulants on the height of chili pepper $(\mathrm{cm})$ grown on different media compositions with limited soil water content (10 WAT)

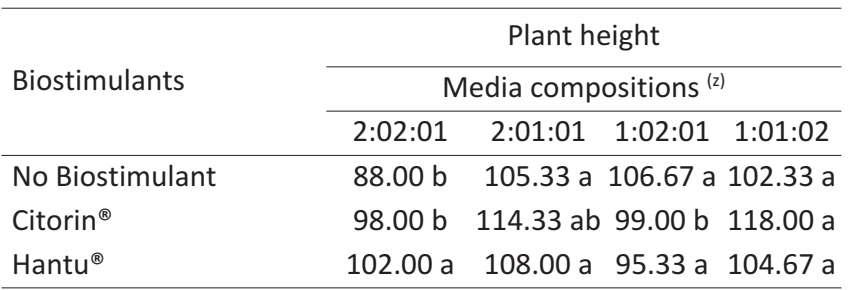

(z) Media compositions= soil : trichocompost : rice husk charcoal. Numbers followed by the same lowercase in the rows are not significantly different according to Fisher's Least Significant Different test $(\alpha=0.05$ ).

The interaction between biostimulants and media compositions showed significant effect on the number of productive branches at 10 WAT (Table 2). The application of Citorin ${ }^{\circledR}$ on plant grown on medium composition of 1:1:2 resulted in the highest number of productive branches, followed by those grown on 2:2:1 medium composition, and they differed significantly from those grown on 1:2:1 medium composition. While in the use of $\mathrm{Hantu}^{\circledR}$, medium composition of 2:2:1 was the best and the effect was significantly different from 1:2:1 and 1:1:2 compositions, but not 2:1:1 composition. In the absence of biostimulant, however, there was no significant difference in the number of productive branches on plants grown on different media compositions (Table 2).

Table 2 - The effect of biostimulants on the number of productive branches of chili pepper grown on different media compositions with limited soil water content (10 WAT)

\begin{tabular}{lcccc}
\hline \multirow{3}{*}{ Biostimulants } & \multicolumn{4}{c}{ Number of productive branches } \\
\cline { 2 - 5 } & \multicolumn{4}{c}{ Media compositions ${ }^{(2)}$} \\
\cline { 2 - 5 } & $2: 02: 01$ & $2: 01: 01$ & $1: 02: 01$ & $1: 01: 02$ \\
\hline No Biostimulant & $88.00 \mathrm{aA}$ & $94.00 \mathrm{aA}$ & $90.66 \mathrm{aA}$ & $71.33 \mathrm{aB}$ \\
Citorin $^{\circledR}$ & $106.66 \mathrm{aA}$ & $96.00 \mathrm{abA}$ & $78.66 \mathrm{bA}$ & 121.33 \\
Hantu $^{\circledR}$ & $112.66 \mathrm{aA}$ & $100.00 \mathrm{abA}$ & $83.00 \mathrm{bA}$ & $79.00 \mathrm{bB}$ \\
\hline
\end{tabular}

(z) Media compositions= soil : trichocompost : rice husk charcoal. Numbers followed by the same lowercase in the rows are not significantly different according to Fisher's Least Significant Different test $(\alpha=0.05)$. 
At 14 WAT, the number of productive branches was not affected by biostimulant application, but the composition of the media was found to affect this parameter significantly (Table 3 ). Hantu $^{\circledR}$ was effective in promoting the number of productive branches on plants grown on medium composition of $2: 1: 1$, $1: 1: 2$ and $2: 2: 1$, which were significantly different from those grown on 1:2:1 medium composition. With Citorin ${ }^{\circledR}$ application as well as in the absence of biostimulant, the effect of media compositions did not show any difference on the number of productive branches (Table 3).

Table 3 - The effect of biostimulants on the number of productive branches of chili pepper grown on different media compositions with limited soil water content (14 WAT)

\begin{tabular}{lcccc}
\hline \multirow{2}{*}{ Biostimulants } & \multicolumn{4}{c}{ Number of productive branches } \\
\cline { 2 - 5 } & \multicolumn{4}{c}{ Media compositions $(\mathrm{z})$} \\
\cline { 2 - 5 } & $2: 02: 01$ & $2: 01: 01$ & $1: 02: 01$ & $1: 01: 02$ \\
\hline No Biostimulant & 161.00 a & 176.67 a & 129.00 a & 170.67 a \\
Citorin ${ }^{\circledR}$ & 195.67 a & 211.00 a & 135.33 a & 186.67 a \\
(z) Media compositions= soil : trichocompost : rice husk charcoal. \\
Numbers followed by the same lowercase in the rows are not sig- \\
nificantly different according to Fisher's Least Significant \\
Different test $(\alpha=0.05)$.
\end{tabular}

The interaction between biostimulants and media compositions did not significantly affect total leaf area and total dry weight (Tables 4 and 5). The largest absolute total leaf area was found in the combination of $\mathrm{Hantu}^{\circledR}$ and 2:1:1 medium composition $\left(2,644.66 \mathrm{~cm}^{2}\right)$ (Table 4). In addition, the greatest total dry weight was obtained in the combination of Citorin ${ }^{\circledR}$ and 1:1:2 medium composition (Table 5).

Significant effect of the interaction between biostimulants and media compositions was noted on dry weight of above-ground parts (Table 6 ), fruit number (Table 7) and fruit weight (Table 8). Data presented in Table 6 show that the dry weight of above-ground parts of plants treated with Citorin ${ }^{\circledR}$ on medium com-

Table 4 - The effect of biostimulants on total leaf area of chili pepper $\left(\mathrm{cm}^{2}\right)$ grown on different media compositions with limited soil water content

\begin{tabular}{lcccc}
\hline \multirow{2}{*}{ Biostimulants } & \multicolumn{4}{c}{ Total leaf area $\left(\mathrm{cm}^{2}\right)$} \\
\cline { 2 - 5 } & $2: 02: 01$ & $2: 01: 01$ & $1: 02: 01$ & $1: 01: 02$ \\
\cline { 2 - 5 } & 1497.46 & 1930.62 & 1827.07 & 1784.26 \\
\hline No Biostimulant & 2115.81 & 2285.40 & 1531.72 & 2361.31 \\
Citorin $^{\circledR}$ & 1997.24 & 2644.66 & 1556.42 & 2413.54 \\
\hline Hantu $^{\circledast}$ &
\end{tabular}

(z) Media compositions= soil : trichocompost : rice husk charcoal. position of 1:1:2 was significantly higher than those without biostimulant. In the absence of biostimulant, media composition of 2:1:1 and 1:2:1 were better than $2: 2: 1$ or $1: 1: 2$, while in the application of Citorin ${ }^{\circledR}$, the composition of $1: 1: 2$ and $2: 1: 1$ were better than 2:2:1 or 1:2:1. However, when Hantu ${ }^{\circledR}$ was applied there was significant difference in the dry weight of above-ground parts of chili peppers grown on all media compositions (Table 6).

Table 5 - The effect of biostimulants on total dry weight of chili pepper (g) grown under drought stress condition on different media compositions with limited soil water content

\begin{tabular}{lcccc}
\hline \multirow{2}{*}{ Biostimulants } & \multicolumn{4}{c}{ Total dry weight } \\
\cline { 2 - 5 } & $2: 02: 01$ & $2: 01: 01$ & $1: 02: 01$ & $1: 01: 02$ \\
\cline { 2 - 5 } & 10.11 & 13.68 & 13.34 & 10.41 \\
No Biostimulant & 11.38 & 14.31 & 11.51 & 16.44 \\
Citorin $^{\circledR}$ & 13.58 & 15.38 & 12.48 & 13.04 \\
Hantu $^{\circledR}$ & (z) & \multicolumn{4}{c}{ Media compositions } \\
\end{tabular}

(z) Media compositions= soil : trichocompost : rice husk charcoal.

Table 6 - The effect of biostimulants on dry weight of aboveground parts of chili pepper (g) grown on different media compositions with limited soil water content

\begin{tabular}{lllll}
\hline \multirow{2}{*}{ Biostimulants } & \multicolumn{4}{c}{ Dry weight } \\
\cline { 2 - 5 } & \multicolumn{4}{c}{ Media compositions ${ }^{(z)}$} \\
\cline { 2 - 5 } & $2: 02: 01$ & $2: 01: 01$ & $1: 02: 01$ & $1: 01: 02$ \\
\hline No Biostimulant & $4.73 \mathrm{bA}$ & $7.13 \mathrm{aA}$ & $6.93 \mathrm{aA}$ & $4.83 \mathrm{bB}$ \\
Citorin $^{\circledR}$ & $5.03 \mathrm{bA}$ & $7.86 \mathrm{aA}$ & $5.93 \mathrm{bA}$ & $8.23 \mathrm{aA}$ \\
Hantu $^{\circledR}$ & $6.60 \mathrm{aA}$ & $7.86 \mathrm{aA}$ & $6.46 \mathrm{aA}$ & $6.50 \mathrm{aAB}$ \\
\hline
\end{tabular}

(z) Media compositions= soil : trichocompost : rice husk charcoal. Numbers followed by the same lowercase in the rows and the same uppercase in the columns are not significantly different according to Fisher's Least Significant Different test $(\alpha=0.05)$.

Data on fruit number presented in Table 7 show that plants grown on media with composition of $2: 2: 1$ and treated with biostimulants produce more fruits than those without biostimulants. On 2:1:1 media composition, the application of $\mathrm{Hantu}^{\circledR}$ resulted in the greatest number of fruit, which was significantly different from either the application of Citorin ${ }^{\circledR}$ or no biostimulant treatment. On 1:1:2 media composition, however, the effect of $\mathrm{Hantu}^{\circledR}$ was significantly different to those plants grown in the absence of biostimulant only. On media composition of 1:2:1, the control treatment produced more fruits than those plants treated with Citorin ${ }^{\circledR}$ (Table 7). 
Table 7 - The effect of biostimulants on the number of fruit of chili pepper grown on different media compositions with limited soil water content

\begin{tabular}{lcccc}
\hline \multirow{3}{*}{ Biostimulants } & \multicolumn{4}{c}{ Fruit number } \\
\cline { 2 - 5 } & \multicolumn{4}{c}{ Media compositions } \\
\cline { 2 - 5 } & $2: 02: 01$ & $2: 01: 01$ & $1: 02: 01$ & $1: 01: 02$ \\
\hline No Biostimulant & $25.00 \mathrm{bB}$ & $38.66 \mathrm{aB}$ & $41.66 \mathrm{aA}$ & $33.00 \mathrm{abB}$ \\
Citorin $^{\circledR}$ & $42.00 \mathrm{aA}$ & $45.33 \mathrm{aB}$ & $24.66 \mathrm{bB}$ & $40.33 \mathrm{aAB}$ \\
Hantu $^{\circledR}$ & $54.00 \mathrm{bA}$ & $73.66 \mathrm{aA}$ & $29.66 \mathrm{cAB}$ & $61.33 \mathrm{abA}$ \\
\hline
\end{tabular}

(z) Media compositions= soil : trichocompost : rice husk charcoal. Numbers followed by the same lowercase in the rows and the same uppercase in the columns are not significantly different according to Fisher's Least Significant Different test $(\alpha=0.05)$.

Data presented in Table 8 show that biostimulant Citorin $^{\circ}$ significantly increased fruit weight when applied on plants grown on medium with 2:2:1 composition. On medium with 1:2:1 composition, the application of either Citorin ${ }^{\circledR}$ or Hantu ${ }^{\circledR}$ was found to result in less fruit weight significantly. In the absence of biostimulant, the composition of 2:1:1 significantly increased fruit weight than 2:2:1 and 1:1:2 media compositions. Also, in the application of $\mathrm{Citorin}^{\circledR}$, the fruit weight of plants grown on medium with the composition of 2:1:1 was significantly heavier than of those grown on medium composition of 1:2:1. Further, in the application of $\mathrm{Hantu}^{\circledR}$ the fruit weight of plants grown on the media composition of 2:1:1 was significantly heavier than the weight fruits produced by plants grown on any other media compositions (Table 8).
Table 8 - The effect of biostimulants on the weight of fruit of chili pepper (g) grown on different media compositions with limited soil water content

\begin{tabular}{lcccc}
\hline \multirow{3}{*}{ Biostimulants } & \multicolumn{4}{c}{ Fruit weight } \\
\cline { 2 - 5 } & \multicolumn{4}{c}{ Media compositions ${ }^{(\mathrm{z})}$} \\
\cline { 2 - 5 } & $2: 02: 01$ & $2: 01: 01$ & $1: 02: 01$ & $1: 01: 02$ \\
\hline No & $54.89 \mathrm{cB}$ & $96.89 \mathrm{aA}$ & $81.08 \mathrm{abA}$ & $67.61 \mathrm{bcA}$ \\
Citorin $^{\circledR}$ & $99.03 \mathrm{abA}$ & $107.75 \mathrm{aA}$ & $31.37 \mathrm{cB}$ & $76.77 \mathrm{bA}$ \\
Hantu $^{\circledR}$ & $67.58 \mathrm{bB}$ & $106.95 \mathrm{aA}$ & $28.70 \mathrm{cB}$ & $71.47 \mathrm{bA}$ \\
\hline
\end{tabular}

(z) Media compositions= soil : trichocompost : rice husk charcoal. Numbers followed by the same lowercase in the rows and the same uppercase in the columns are not significantly different according to Fisher's Least Significant Different test ( $\alpha=0.05$ ).

The use of biostimulants and growing media containing soil+trichocompost+rice husk charcoal was able to maintain nutrient status within plant tissues to remain at optimal level during limited soil water availability, except for potassium which was at luxury consumption level and calcium which was below critical limit. Nutrient content of chili leaf tissues was measured when the plant was 14 weeks old after transplanting. The results of leaf tissue nutrient measurement is presented in Table 9.

Plants grown on different media compositions and treated with both Citorin ${ }^{\circledR}$ and $\mathrm{Hantu}^{\circledR}$ showed a higher total sugar and chlorophyll contents and lower proline level compared to those without biostimulant application (control). In spite of media compositions, plants treated with Citorin ${ }^{\circledR}$ show a higher total sugar and lower proline content in comparison to those

Table 9 - Leaf nutrient contents of chili pepper as affected by biostimulants and different media compositions during limited soil water availability

\begin{tabular}{|c|c|c|c|c|c|c|}
\hline \multirow{2}{*}{ Biostimulants } & \multirow{2}{*}{$\begin{array}{c}\text { Media }^{(z)} \\
\text { compositions }\end{array}$} & \multicolumn{5}{|c|}{ Leaf tissue nutrient content (\%) (y) } \\
\hline & & $\mathrm{N}$ & $P$ & $\mathrm{~K}^{+}$ & $\mathrm{Ca}^{2+}$ & $\mathrm{Mg}^{2+}$ \\
\hline \multirow[t]{4}{*}{ No biostimulant } & 2:02:01 & 2.46 & 0.31 & 7.22 & 0.88 & 0.56 \\
\hline & 2:01:01 & 1.94 & 0.37 & 6.22 & 1.18 & 0.73 \\
\hline & 1:02:01 & 2.55 & 0.32 & 6.53 & 1.02 & 1.05 \\
\hline & 1:01:02 & 3.01 & 0.26 & 6.13 & 1.03 & 1.02 \\
\hline \multirow[t]{4}{*}{ Citorin $^{\circledR}$} & 2:02:01 & 3.21 & 0.33 & 4.37 & 1.01 & 0.86 \\
\hline & 2:01:01 & 2.83 & 0.31 & 5.99 & 1.12 & 0.89 \\
\hline & 1:02:01 & 3.12 & 1.34 & 8.24 & 0.85 & 0.44 \\
\hline & 1:01:02 & 3.11 & 0.30 & 7.03 & 0.85 & 0.99 \\
\hline \multirow[t]{4}{*}{ Hantu $^{\circledast}$} & 2:02:01 & 3.44 & 0.29 & 7.78 & 1.05 & 0.72 \\
\hline & 2:01:01 & 3.65 & 0.31 & 5.83 & 1.08 & 0.61 \\
\hline & 1:02:01 & 3.14 & 0.34 & 7.47 & 0.65 & 0.48 \\
\hline & 1:01:02 & 3.02 & 0.30 & 7.67 & 0.86 & 0.93 \\
\hline
\end{tabular}

(z) Media compositions= soil : trichocompost : rice husk charcoal.

(y) Leaf nutrient content was determined compositely by physically mixing individual leaves taken from each 3 sample plants of 3 repli- 
treated with Hantu ${ }^{\circledR}$. However, plants grown on medium composition of $1: 1: 2$ and treated with Hantu ${ }^{\circledR}$ produced the highest chlorophyll content.

Total sugar, proline and chlorophyll content of leaves were measured when the plants were 14 weeks after planting, and the results are presented in Table 10.

\section{Discussion and Conclusions}

The application of biostimulants on chili pepper grown on different growing media compositions with limited soil water content was found to increased plant growth and yield. Our results proved that biostimulant application was important for chili pepper grown on media consisting of soil+trichocompost+rice husk charcoal but with limited water supply. Plants treated with biostimulants grew better than those without biostimulant on all growing media. Plants treated with either Citorin ${ }^{\circledR}$ or Hantu ${ }^{\circledR}$ and grown on soil+trichocompost+rice husk charcoal with ratio of 2:1:1 were taller and bigger than those grown on other media compositions without biostimulant application (Fig. 1 and Fig. 2). This increased in pepper growth and yield is presumably due to hormones, organic acids, and macro and micro nutrients contained within the biostimulants. Citorin ${ }^{\circledR}$ contains gibberellic acid $\left(\mathrm{GA}_{3}\right)$ along with nutrients such as $\mathrm{P}$, $\mathrm{K}, \mathrm{Mg}, \mathrm{Mn}$, antioxidants and vitamins (Amanah and Putra, 2018). Meanwhile, Hantu ${ }^{\circledR}$ contains the gibberellic acids $\left(\mathrm{GA}_{3}, \mathrm{GA}_{5}, \mathrm{GA}_{7}\right)$, IAA, kinetin and zeatin along with nutrients such as $\mathrm{N}, \mathrm{P}, \mathrm{Na}, \mathrm{Mg}, \mathrm{Cu}, \mathrm{Fe}, \mathrm{Mn}$, $\mathrm{Zn}, \mathrm{Co}, \mathrm{Cd}$, and $\mathrm{Pb}$ (Lidar and Mutryarny, 2017).

Hedden and Thomas (2012) claimed that GA physiologically acted as growth stimulant of plant organs through cell division and elongation. Further, Gupta and Chakrabarty (2013) suggested that gibberellic

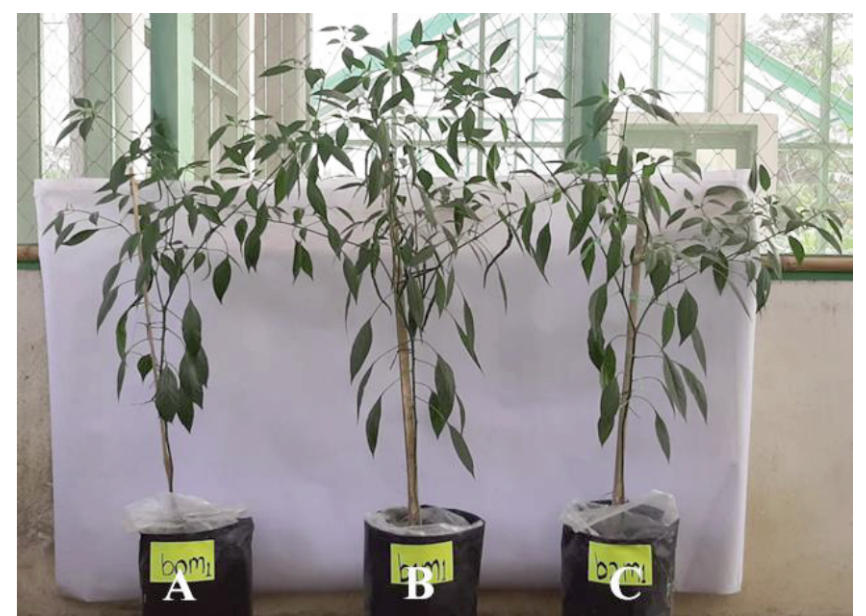

Fig. 1 - The effect of biostimulants on the growth of chili pepper during limited water supply $(A=$ no biostimulant; $B=$ Citorin $^{\circledR} ; \mathrm{C}=$ Hantu $^{\circledR}$ ).

Table 10 - Total sugar, proline and chlorophyll contents as affected by biostimulants and different media compositions during limited soil water availability

\begin{tabular}{|c|c|c|c|c|c|c|}
\hline \multirow{2}{*}{ Biostimulants } & \multirow{2}{*}{$\begin{array}{c}\text { Media }(z) \\
\text { compositions }\end{array}$} & \multirow{2}{*}{$\begin{array}{l}\text { Total sugar }(\mathrm{y}) \\
\quad\left(\mathrm{mg} \mathrm{g}^{-1}\right)\end{array}$} & \multirow{2}{*}{$\begin{array}{l}\text { Proline }{ }^{(y)} \\
\left(\mathrm{mM} \mathrm{g}^{-1}\right)\end{array}$} & \multicolumn{3}{|c|}{ Chlorophyll (y) $\left(\mathrm{cm}^{2} \mathrm{~mL}^{-1}\right)$} \\
\hline & & & & a & $b$ & Total \\
\hline \multirow[t]{4}{*}{ No biostimulant } & 2:02:01 & 3.045 & 0.925 & 6.096 & 9.523 & 15.619 \\
\hline & 2:01:01 & 3.136 & 0.592 & 6.688 & 10.175 & 16.863 \\
\hline & 1:02:01 & 2.091 & 1.048 & 7.386 & 11.380 & 18.766 \\
\hline & 1:01:02 & 3.091 & 0.304 & 7.527 & 10.695 & 18.222 \\
\hline \multirow[t]{4}{*}{ Citorin $^{\circledast}$} & 2:02:01 & 3.136 & 0.439 & 7.731 & 11.723 & 19.455 \\
\hline & 2:01:01 & 4.841 & 0.254 & 8.366 & 11.325 & 19.691 \\
\hline & 1:02:01 & 2.614 & 0.921 & 5.252 & 7.109 & 12.361 \\
\hline & $1: 01: 02$ & 3.909 & 0.347 & 7.585 & 10.568 & 18.154 \\
\hline \multirow[t]{4}{*}{ Hantu $^{\circledR}$} & 2:02:01 & 4.091 & 1.209 & 7.430 & 9.888 & 17.318 \\
\hline & 2:01:01 & 3.727 & 0.803 & 6.681 & 9.217 & 15.899 \\
\hline & 1:02:01 & 3.864 & 1.141 & 3.723 & 5.076 & 8.799 \\
\hline & 1:01:02 & 2.455 & 0.566 & 8.695 & 12.011 & 20.706 \\
\hline
\end{tabular}

(z) Media compositions= soil : trichocompost : rice husk charcoal.

(y) Total sugar, proline and chlorophyll contents was determined compositely by physically mixing individual leaves taken from each 3 sample plants of 3 replicates into one homogenous sample at 10 weeks after transplanting. 
acids in plants played an important role in triggering the transition from meristem to shoot growth until mature organs. Various recent studies on the use of gibberellic acids indicated that these plant hormones could increase plant growth and development, improved yield, and increased tolerance to abiotic stresses such as drought, heat and salinity (Pal et al., 2016; Sarwar et al., 2017; Miceli et al., 2019; Zhu et al., 2019).

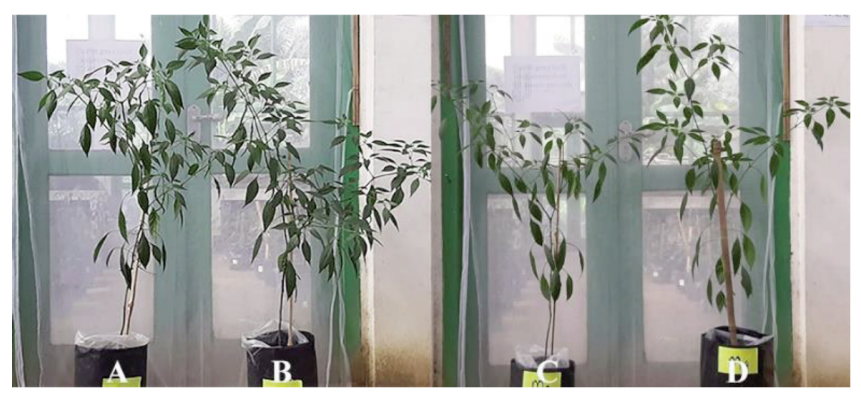

Fig. 2 - The effect of the ratio of soil+trichocompost+rice husk charcoal on the growth of chili pepper during limited water supply $(A=2: 1: 1 ; B=2: 2: 1 ; C=1: 2: 1 ; D=1: 1: 2)$.

Growing media is one of important elements supporting plant growth and development. A good media should have good aeration, be able to hold water, and capable to store nutrients for plants. The mixture of soil+trichocompost+rice husk charcoal with the ratio of $2: 1: 1$ or $1: 1: 2$ produced better plant growth compared to others. The greatest plant height, total leaf area and dry weight of aboveground parts were achieved on plants grown on media with the ratio of $2: 1: 1$ on all biostimulant applications, except Citorin ${ }^{\circledR}$ on 1:1:2 medium composition. Meanwhile, the highest number of productive branches (aged 10 and 14 WAT) was obtained on medium composition of $2: 1: 1$ in all biostimulant applications. Based on these results it can be seen that media with more soil or more rice husk charcoal were preferable to produce better growth of chili pepper treated with biostimulants.

Trichocompost is Trichoderma-based fertilizer that function to enhance plant's drought tolerance by improving root development (Shukla et al., 2012), activating antioxidant protection to prevent damage caused by dehydration (Brotman et al., 2013), and delaying changes in stomatal opening, photosynthesis and chlorophyll content due to drought (LópezBucio et al., 2015). Trichoderma sp. help plants better resist environmental stress such as drought via reinforcing plant growth and reprograming gene expression in roots and shoots. The tolerance to water deficit was attributed to activation of antioxidant responses and higher activity of ascorbate and glutathione-recycling enzymes (Mastouri et al., 2012). The fungal mycelium secreted different compounds that increase the branching capacity of the root system, thus improving nutrient and water acquisition (López-Bucio et al., 2015).

Good growth performance of chili pepper grown on soil+trichocompost+rice husk charcoal and sprayed with biostimulants was followed by good production in term of fruit number and weight. These result was the consequence of a significant interaction of the two factors. Moreover, plants grown in medium with ratio of 2:1:1 and sprayed with Citorin ${ }^{\circledR}$ produced higher total sugar and chlorophyll content and lower in proline compared to those grown on the same medium but in the absence of biostimulant, as well as plants grown on other media ratios but treated with $\mathrm{Hantu}^{\circledR}$.

Total sugar content in chili pepper grown on soil+trichocompost+rice husk charcoal with ratio of 2:1:1 and treated with biostimulants was higher than those grown on other media but in the absence of biostimulant. The results of this study are in line with study conducted by Martim et al. (2009) on grapevines which showed that drought stress could increase respiration rate of plants. Increased respiration rate will lower plant carbohydrates and promote total sugar content which also function as an osmotic adjustment.

Chloroplast contains chlorophyll which is a major component involving in photosynthesis. Decrease in chlorophyll content during drought was an indication of oxidative stress caused by photo-oxidative pigment and chlorophyll degradation (Farooq et al., 2009; Anjum et al., 2011). The increase of chlorophyll content in chili peppers grown on different ratios of soil+trichocompost+rice husk charcoal indicates that the plants were able to survive drought stress condition. The application of biostimulants may thus improve plant physio-biochemical attributes under drought stress. This is in accordance with the results noted on Triticum aestivum and Solanum lycopersicum (Yasmeen et al., 2013) and Phaseolus vulgaris (Rady and Mohamed, 2015; Elzaawely et al., 2017). El-Mageed et al. (2017) claimed that the improvement of chlorophyll content due to biostimulant application under drought stress may be attributed to the protection impacts on the photosynthetic systems.

Proline is one of dissolved compounds produced 
by plants in drought stress condition, which acts as an osmotic adjustment in addition to other compounds such as fructan, trehalose, polyol, polyamine and glycinbetain (Mitra, 2001). As an osmotic adjustment, proline keeps plants to continue to grow even in a low water potential condition. Low proline content in plants grown on media ratio of 2:1:1 and treated with Citorin ${ }^{\circledR}$ indicates that they do not experience stress due to drought. This is in accordance with report by Goñi et al. (2018) on tomato grown on limited soil water content and treated with Ascophyllum nodosum extract which showed a lower leaf proline content in comparison to untreated plants.

Biostimulants containing bioactive compounds are desirable in today's agriculture because of their capability to enhance nutrient uptake which positively affect overall plant vigor resulting in high quantity and quality of harvest (Parađiković et al., 2017). In our study biostimulant application on chili pepper grown on soil+trichocompost+rice husk charcoal could improve growth, increase nutrient status as well as total sugar and chlorophyll contents, and reduce proline level in leaves. In addition, plant height, number of productive branches, total leaf area, and dry weight of above-ground parts were higher in biostimulant-treated plants. Biostimulant Citorin ${ }^{\circledR}$ might be used to ensure the production of chili pepper by overcoming drought stress and providing good nutrient uptake on medium consists of soil+trichocompost+rice husk charcoal with ratio of 2:1:1.

Further works would be necessary to study the application different concentrations of $\mathrm{Citorin}^{\circledR}$ on plants grown on 2:1:1 media composition to find out their effects on the yield.

\section{Acknowledgements}

We are very grateful His Magnificence Rector of the University of Jambi in Jambi, Indonesia for the financial support of this study through the Competitive Internal Research Grant under the Professor Acceleration Research Scheme 2019.

\section{References}

AMANAH D.M., PUTRA S.M., 2018 - Effect of biostimulants on drought tolerance and growth of sugarcane var.
Kidang Kencana at green house. - Menara Perkebunan, 86(1): 46-55.

ANJUM S.A., XIE X.-Y., WANG L.-C., SALEEM M.F., MAN C., LEI W., 2011 - Morphological, physiological and biochemical responses of plants to drought stress. - Afr. J. Agric. Res., 6(9): 2026-2032.

BAE H., SICHER R.C., KIM M.S., KIM S.-H., STREM M.D., MELNICK R.L., BAILEY B.A., 2009 - The beneficial endophyte Trichoderma hamatum isolate DIS $219 \mathrm{~b}$ promotes growth and delays the onset of the drought response in Theobroma cacao. - J. Exp. Bot., 60(11): 3279-3295.

BATES L.S., WALDREN R.P., TEARE I.D., 1973 - Rapid determination of free proline for water-stress studies. - Plant Soil, 39: 205-207.

BROTMAN B., LANDAU A., CUADROS-INOSTROZA A., TAKAYUKI T., FERNIE A., CHET I., VITERBO A., WILLMITZER L., 2013 - Trichoderma-plant root colonization: escaping early plant defense responses and activation of the antioxidant machinery for saline stress tolerance. - PLoS Pathog., 9(4): e1003221.

CARTER S., SHACKLEY S., SOHI S., SUY T.B., HAEFELE S., 2013 - The impact of biochar application on soil properties and plant growth of pot grown lettuce (Lactuca sativa) and cabbage (Brassica chinensis). - Agronomy, 3(2): 404-418.

DROBEK M., FRĄC M., CYBULSKA J., 2019 - Plant biostimulants: importance of the quality and yield of horticultural crops and the Improvement of plant tolerance to abiotic stress - a review. - Agronomy, 9(6): 335.

EL-MAGEED T.A.A., SEMIDA W.M., RADY M.M., 2017 Moringa leaf extract as biostimulant improves water use efficiency, physio-biochemical attributes of squash plants under deficit irrigation. - Agric. Water Manag., 193: 46-54.

ELZAAWELY A.A., AHMED M.E., MASWADA H.F., XUAN T.D., 2017 - Enhancing growth, yield, biochemical, and hormonal contents of snap bean (Phaseolus vulgaris L.) sprayed with Moringa leaf extract. - Arch. Agron. Soil Sci., 63(5): 687-699.

FAROOQ M., WAHID A., KOBAYASHI N., FUJITA D., BASRA S.M.A., 2009 - Drought stress: effects, mechanisms and management. - Agron. Sustain. Dev., 29(1): 185-212.

GOÑI O., QUILLE P., O'CONNELL S., 2018 - Ascophyllum nodosum extract biostimulants and their role in enhancing tolerance to drought stress in tomato plants. - Plant Physiol. Bioch., 126: 63-73.

GUPTA R., CHAKRABARTY S.K., 2013 - Gibberellic acid in plant. - Plant Signaling \& Behavior, 8(9): 1-5.

HALL D.O., RAO K.K., 1986 - Photosynthesis. Fourth Edition. - Edward Arnold, London, UK, pp. 128.

HEDDEN P., THOMAS S.G., 2012 - Gibberellin biosynthesis and its regulation. - Biochem. J., 444(1): 11-25.

ICHWAN B., SUWIGNYO R.A., HAYATI R., SUSILAWATI S., 2017 - Response of red chilli varieties under drought stress. - Russ. J. Agric. Socio-Economic Sci., 6(66): 361- 
368.

IMANDA N., KETTY S., 2018 - The effect of growing media types on planting seedlings papaya (Carica papaya L.) IPB 3, IPB 4, and IPB 9 genotypes. - Buletin AgroHorti, 6(1): 99-111.

IRIGOYEN J.J., EMERICH D.W., SÁNCHEZ DÍAZ M., 1992 Water stress induced changes in concentrations of proline and total soluble sugars in nodulated alfalfa (Medicago sativa) plants. - Physiol. Plant., 84: 55-60.

KARLBERG B., PACEY G.E., 1989 - Techniques and instrumentation in analytical chemistry. Volume 10. Flow injection analysis. A Practical Guide. - Elsevier Science Publishers B.V, Amsterdam, The Netherlands.

KHOSHMANZAR E., ALIASGHARZAD N., NEYSHABOURI M.R., KHOSHRU B., ARZANLOU M., LAJAYER B.A., 2019 - Effects of Trichoderma isolates on tomato growth and inducing its tolerance to water-deficit stress. - Int. J. Environ. Sci. Technol., 17: 869-878.

LABCONCO CORPORATION, 1998 - A guide to Kjeldahl nitrogen determination methods and apparatus. Labconco Corporation, Kansas City, USA.

LIDAR S., MUTRYARNY E., 2017 - Uji ZPT Hantu terhadap pertumbuhan dan produksi selada merah (Lactuca sativa). - Journal Ilmiah Pertanian, 3(2): 89-96.

LÓPEZ-BUCIO J., PELAGIO-FLORES R., HERRERA-ESTRELLA A., 2015 - Trichoderma as biostimulant: exploiting the multilevel properties of a plant beneficial fungus. - Sci. Hort., 196: 109-123.

MANNAN M.A., SHASHI M.A., 2019 - Amelioration of drought tolerance in maize using rice husk biochar. - In: HOSSAIN A. (ed.) Maize. Production and use. IntechOpen Limited, London, UK.

MARTIM S.A., SANTOS M.P., PECANHA A.L., POMMER C., CAMPOSTRINI E., VIANA A.P., FACANHA A.R., BRESSANSMITH R., 2009 - Photosynthesis and cell respiration modulated by water deficit in grapevine (Vitis vinifera L.) cv. Cabernet Sauvignon. - Braz. J. Plant Physiol., 21(2): 95-102.

MASTOURI F., BJÖRKMAN T., HARMAN G.E., 2010 - Seed treatment with Trichoderma harzianum alleviates biotic, abiotic, and physiological stresses in germinating seeds and seedlings. - Phytopathology, 100(11): 12131221.

MASTOURI F., BJÖRKMAN T., HARMAN G.E., 2012 Trichoderma harzianum enhances antioxidant defense of tomato seedlings and resistance to water deficit. Mol. Plant Microbe Interact., 25(9): 1264-1271.

MICELI A., MONCADA A., SABATINO L., VETRANO F., 2019 Effect of gibberellic acid on growth, yield, and quality of leaf lettuce and rocket grown in a floating System. Agronomy, 9: 382.

MISHRA A., TAING K., HALL M.W., SHINOGI Y., 2017 Effects of rice husk and rice husk charcoal on soil physicochemical properties, rice growth and yield. Agric. Sci., 8: 1014-1032.
MITRA J., 2001 - Genetics and genetic improvement of drought resistance in crops plants. - Curr. Sci., 80(6): 758-763.

NIYOKURI A.N., NYALALA S., MWANGI M., 2018 - Residual effects of bioslurry and amino acids plant biostimulant on carnation (Dianthus caryophyllus L.) flower quality. Adv. Hort. Sci., 32(1): 137-142.

PAL P., YADAV K., KUMAR K., SINGH N., 2016 Cummulative effect of potassium and gibberellic acid on growth, biochemical attributes and productivity of F1 hybrid cucumber. - Environ. Exp. Biol., 14: 57-61.

PARAĐIKOVIĆ N., ZELJKOVIĆ S., TKALEC M., VINKOVIĆ T., MAKSIMOVIĆ I., HARAMIJA J., 2017 - Influence of biostimulant application on growth, nutrient status and proline concentration of Begonia transplants. - Biol. Agric. Hortic., 33(2): 89-96.

PETERSEN R.G., 1985 - Design and analysis of experiments. - Marcel Dekker Inc., New York, USA, pp. 436.

RADY M.M., MOHAMED G.F., 2015 - Modulation of salt stress effects on the growth, physio-chemical attributes and yields of Phaseolus vulgaris L. plants by the combined application of salicylic acid and Moringa oleifera leaf extract. - Sci. Hort., 193: 105-113.

RADY M.M., UR REHMAN H., 2016 - Supplementing organic biostimulants into growing media enhances growth and nutrient uptake of tomato transplants. - Sci. Hort., 203: 192-198.

SARWAR N., UR-RAHMAN A., FAROOQ O., MUBEEN K., WASAYA A., NOUMAN W., ALI M.Z., SHEHZAD M., 2017 - Exogenous application of gibberellic acid improves the maize crop productivity under scarce and sufficient soil moisture content. - Cercetări Agronomice în Moldova, 50(4): 65-73.

SHUKLA N., AWASTHI R.P., RAWAT L., KUMAR J., 2012 Biochemical and physiological responses of rice (Oryza sativa L.) as influenced by Trichoderma harzianum under drought stress. - Plant Physiol. Bioch., 54: 78-88.

STATISTICS INDONESIA, 2019 - Statistics of seasonal vegetables and fruits plants Indonesia, 2018. - BPSStatistics Indonesia, Jakarta.

THE PERKIN-ELMER CORPORATION, 1996 - Analytical methods for atomic absorption spectroscopy. - The Perkin-Elmer Corporation, United States of America.

YASMEEN A., BASRA S.M.A., FAROOQ M., REHMAN H.U., HUSSAIN N., ATHAR H.U.R., 2013 - Exogenous application of moringa leaf extract modulates the antioxidant enzyme system to improve wheat performance under saline conditions. - Plant Growth Regul., 69(3): 225233.

ZHU G., AN L., JIAO X., CHEN X., ZHOU G., McLAUGHLIN N., 2019 - Effects of gibberellic acid on water uptake and germination of sweet sorghum seeds under salinity stress. - Chil. J. Agric. Res., 79(3): 415-424.

ZULKARNAIN, 2013 - Budi Daya Sayuran Tropis. - PT Bumi Aksara, Jakarta. 
